\title{
Correction to: The relevance of body mass index in forensic age assessment of living individuals: an age-adjusted linear regression analysis using multivariable fractional polynomials
}

\author{
Maximilian Timme ${ }^{1} \cdot$ André Karch $^{2} \cdot$ Denys Shay $^{2} \cdot$ Christian Ottow $^{3} \cdot$ Andreas Schmeling $^{1}$
}

Published online: 12 August 2021

(c) The Author(s) 2021

\section{Correction to: International Journal of Legal Medicine (2020) 134:1861-1868 https://doi.org/10.1007/s00414-020-02381-2}

The article "The relevance of body mass index in forensic age assessment of living individuals: an age-adjusted linear regression analysis using multivariable fractional polynomials", written by Maximilian Timme, André Karch, Denys Shay, Christian Ottow and Andreas Schmeling, was originally published Online First without Open Access. After publication in volume 134, issue 5, page 1861-1868 the author decided to opt for Open Choice and to make the article an Open Access publication. Therefore, the copyright of the article has been changed to (C) The Author(s) 2020 and the article is forthwith distributed under the terms of the Creative Commons Attribution 4.0 International License, which permits use, sharing, adaptation, distribution and reproduction in any medium or format, as long as you give appropriate credit to the original author(s) and the source, provide a link to the Creative Commons licence, and indicate if changes were made. The images or other third party material in this article are included in the article's Creative Commons licence, unless indicated otherwise in a credit line to the material. If material is not included in the article's Creative Commons licence and your intended use is not

The original article can be found online at https://doi.org/10.1007/ s00414-020-02381-2.

Maximilian Timme

m.timme@uni-muenster.de

1 Institute of Legal Medicine, University Hospital Muenster, Röntgenstraße 23, 48149 Münster, Germany

2 Institute of Epidemiology and Social Medicine, University of Muenster, Domagkstraße 3, 48149 Münster, Germany

3 Department of Clinical Radiology, University Hospital Muenster, Albert-Schweitzer-Campus 1, 48149 Münster, Germany permitted by statutory regulation or exceeds the permitted use, you will need to obtain permission directly from the copyright holder. To view a copy of this licence, visit http:// creativecommons.org/licenses/by/4.0.

The original article has been corrected.

Open Access This article is licensed under a Creative Commons Attribution 4.0 International License, which permits use, sharing, adaptation, distribution and reproduction in any medium or format, as long as you give appropriate credit to the original author(s) and the source, provide a link to the Creative Commons licence, and indicate if changes were made. The images or other third party material in this article are included in the article's Creative Commons licence, unless indicated otherwise in a credit line to the material. If material is not included in the article's Creative Commons licence and your intended use is not permitted by statutory regulation or exceeds the permitted use, you will need to obtain permission directly from the copyright holder. To view a copy of this licence, visit http://creativecommons.org/licenses/by/4.0/.

Publisher's note Springer Nature remains neutral with regard to jurisdictional claims in published maps and institutional affiliations. 